\title{
MAXIMIZING OF SURFACE IRRIGATION PERFORMANCE ON GROWTH AND PRODUCTION OF COWPEA IN CLAY SOIL
}

\section{Khalifa, S. M.1' A. M. Okasha'; R. A. Hegazi ${ }^{2}$ and A. A. Hommos \\ ABSTRACT}

Alternate furrow irrigation (AFI) is gaining interest as a mean of saving water while minimizing loss in crop production. Field experiment was conducted in the Experimental Farm, Faculty of Agriculture, Kafrelsheikh University, Egypt, during growing season of 2016-2017. The present work included the following: Irrigation systems (Furrow surface irrigation and surface drip irrigation (SDI)). However, different techniques had been investigated with surface irrigation (alternative furrow (AFI) and conventional furrow irrigation (CFI) with a furrow length of 20, 30 and 40 $m$. The experiment was designed as split plot with three replications, where irrigation systems used as the main plot and furrow length as sub-plot. The ranges of mean cowpea yield gained from irrigation system were 932.33, 910.52 and $1179.52 \mathrm{~kg} /$ fed for CFI, AFI and SDI respectively. The effect of furrow length and their interaction with irrigation system on yield were nonsignificant but the irrigation system has significant effect on yield $(P<0.01)$. The maximum and minimum yield was obtained at length of $20 \mathrm{~m}$ for SDI and length of $40 \mathrm{~m}$ for AFI, which were $34.37 \mathrm{~kg}$ and $25.26 \mathrm{~kg}$, respectively. The effect of irrigation system on the water use efficiency (WUE) was significant $(p<0.01)$. The average WUE was decreased from 11.57 to 8.10 $\mathrm{kg} / \mathrm{m}^{3}$ when the furrow length increased from $20 \mathrm{~m}$ to $40 \mathrm{~m}$. The range of mean values of WUE due to the effect of furrow length from 20 to 40m was highly significant $(P<0.01)$ only. The average of WUE was increased from 5.81 to 9.87 and $13.41 \mathrm{~kg} / \mathrm{m}^{3}$ for CFI, AFI and SDI systems, respectively. The highest and lowest values of irrigation depth (ID), water application efficiency (WAE), water distribution efficiency (WDE) and applied water $(A W)$ were $17.65-10.12 \mathrm{~cm}, 75.25-52.46 \%, 73.37-36.45 \%$ and 61.20 .

1 Professor of Agric. Eng., Agric. Eng. Dept., Faculty of Agric., Kafrelsheikh University.

2 Associate Prof of Agric. Eng., Agric. Eng. Dept., Faculty of Agric., Kafrelsheikh University. 3 Post-Graduate, Agric. Eng. Dept., Faculty of Agric., Kafrelsheikh University. 


\section{INTRODUCTION}

W ater shortage is the most important factor constraining agricultural production in arid and semi-arid regions. Thus, new irrigation strategies must be established to use the limited water resource more efficiently. The growing pressure on fresh water resources has been widely acknowledged, and there is need for water resources to be managed better (Sander and Lucie 2010). In most Egyptian areas irrigated agriculture has been faced with increased limitations of water supply in the last few decades. To reduce the disproportion between water demand and supply, water management is required, particularly aimed at water saving and conservation in irrigated agriculture. One main way is demand management by reducing the irrigation water demand by improved crop irrigation management. In this perspective specially improved furrow irrigation alternatives such as AFI. CFI have been developed to enable intensive production in the ASALs (Montoro et al. 2011). In Egypt, Cowpea (Vigna unguiculata L. Walp) is grown on 14,830 feddan with production 17248 tons with (an average yield of 1.163 ton/feddan), according to the Agricultural economic bulletin (El-Shaieny 2017). Cowpea regarded as a major pulse crop amongst the vegetable legumes that existing at West Africa. Further, belongs to family, and had a little seedling establishment and growth duration (Chiulele, 2010). The cheapest and easiest adaptations are those of furrow irrigation. An important adaptation of furrow irrigation is Alternate Furrow Irrigation (AFI) in which furrows are irrigated alternately rather than consecutively during irrigation water application. This is a form of partial root-zone drying (PRD) system which has been found to increase the production of crops in the ASAL areas (Stickic et al. 2003). Alternate Furrow Irrigation (AFI), is a modified form of Regulated Deficit Irrigation technique which can improve the water use efficiency of crop production without significant yield reduction (Fereres and Soriano 2007). Du et al. (2010) and Horst et al.(2005) indicated that the efficiency of conventional furrow irrigation (CFI), referred to be some as every furrow irrigation, can be improved by converting it to alternate furrow irrigation (AFI). The AFI technique is essentially the same as CFI, except that instead of irrigating every 
furrow, irrigation is applied to alternate furrows, while the in-between furrows remain dry. This means each ridge receives water from only one side, and the side receiving irrigation water could be changed with each irrigation if the field is set up to facilitate this change. Irrigating just one side of the ridge means there is significant potential to save irrigation water compared to CFI. There is however, also potential in some cases for a reduction in crop yield (Mashori 2013). Felipe et al. (2011) stated that alternate furrow irrigation (AFI) reduced applied water by $25 \%$ without a decrease in yields, compared with every furrow irrigation for Tomato plants and Agronomic water use efficiency was 30\% higher in alternate furrow irrigation than every furrow irrigation. Alternate furrow irrigation is a way to use less water without a decrease in yield or fruit quality, and without investment in technology such as drip irrigation. Mulei (2015) stated that (AFI), is a practical water saving technique that can enable at least $42 \%$ to $46 \%$ water savings. In agreement with other studies in the past, this study supports the conclusion that AFI is a practical water saving system that if adopted can enable increase to horticulture production in arid areas because most of these ASAL areas face diminishing water resources. Yigezu and Narayanan (2016) showed that the use of different furrow length and flow rate has shown different outcomes. The use of short furrow length was the major contributor of water loss through surface runoff and reduced yield. Hence, in the utilization of fragmented farm size, the combination of $48 \mathrm{~m}$ furrow length and 0.791/s flow rate can be used for better crop yield, and irrigation efficiency. In addition, the users should give much emphasis in reducing furrow gradient in order to improve the distribution uniformity. In open-ended short furrow utilization, runoff losses were greater over deep percolation loss. Siyala et al. (2016) indicated that the total irrigation water applied with AFI treatment was roughly half $(248 \pm 2.9$ $\mathrm{mm}$ ) that applied to the CFI treatment $(497 \pm 1.7 \mathrm{~mm})$. Despite the very significant reduction in irrigation water used with AFI there was a nonsignificant $(\mathrm{p}>0.05)$ reduction $(7.3 \%)$ in okra yield. As a result, we also obtained a significantly $(\mathrm{p}<0.001)$ higher crop water productivity (CWP) of5.29 $\pm 0.1 \mathrm{~kg} \mathrm{~m}-3$ with AFI, which was nearly double the 2.78 $\pm 0.04 \mathrm{~kg} \mathrm{~m}-3$ obtained with CFI. While this reduction in yield and/or 
potential income may appear small, it could be critical to the welfare of individual farmers, who may as a result hesitate to make changes from CFI to AFI if they are worse off than farmers who do not adopt AFI. Bahrani and Pourreza (2016) found that the Irrigation techniques (AFI and FFI) reduced rapeseed yields by 20 and $25 \%$ compared to FI irrigation. The AFI and FFI irrigation strategies were equally effective in saving irrigation water. Alternate furrow irrigation practice for rapeseed provides water use efficiency benefit compared to full irrigation (CFI). The value of benefits from water saving should be balanced with the value of yield reductions and the cost of implementing alternative irrigation system compared to conventional systems. Assefa $S$ et al. (2017) showed that the interaction effects of furrow lengths and flow rates were significantly $(\mathrm{p}<0.05)$ different in influencing application efficiency. Also it was significantly affected $(\mathrm{P}<0.01)$ by interaction of furrow length and flow rate with highest value of $89.32 \%$ for $200 \mathrm{~m}$ length and 6 lit/s. Storage efficiency was significantly affected $(\mathrm{P}>0.01)$ by the interaction with highest value of $100 \%$ for treatment combination of $200 \mathrm{~m}$ furrow length and $4 \mathrm{lit} / \mathrm{s}$; lowest value of $99.06 \%$ for $100 \mathrm{~m}$ and 6 lit/s effect of furrow length and flow rate. Golzardi et al. (2017) found that the potential of AFI for development of water-saving strategies for maize production in semi-arid climates where, Implementation of AFI resulted in a significant saving in irrigation water. At I70, 31\% less water was used with AFI than with EFI. Regardless of irrigation regime, IWUE under AFI was always greater than under EFI. In addition, plants were shorter with a longer root system under AFI. Yield reduction due to water stress was attributed to decline in both kernel number and kernel weight. Improvement of water productivity in irrigation system can be achieved by applying the required amount of crop water at the right time. This includes proper design of furrow length and irrigation period. It has been observed that farmers prefer to stick with traditional furrow irrigation system due to its simplicity, ease of operation and maintenance and low installation/construction cost from other systems such as pressurized drip irrigation (PDI). If the conventional furrow irrigation system (CFI) is transformed into alternate furrow irrigation (AFI) then it might be readily accepted by farmers. However, before introducing and advocating this 
system to local farmers for adoption, the system needs to be evaluated under soil and climatic conditions representative of the areas being targeted for its introduction.

The objectives of this study were to evaluate the effect of alternate furrow irrigation (AFI) water saving technique on growth and yield compared with conventional furrow (CFI) and surface drip irrigation (SDI) to maximizing of surface irrigation performance on growth and production of cowpea in clay soil of north Delta in Egypt.

\section{MATERIALS AND SYSTEMS}

\subsection{Site Description}

The field experiments were conducted at experimental farm of Faculty of Agriculture, Kafrelsheikh University, Kafrelsheikh Governorate, Egypt that located at $31^{\circ} 6 \mathrm{~N}$ latitude, $30^{\circ} 50 \mathrm{E}$ longitude and altitude $6 \mathrm{~m}$, during the summer season 2016/2017. The experimental site was ploughed four times by using chisel plough (7 shares). Cowpea (Vigna unguiculata L. Walp Strain 2) was planted in manually on the 30 of June 2016 after Egyptian clover crop. The distance between rows was $60 \mathrm{~cm}$ and between plants was $25 \mathrm{~cm}$ included four rows of cowpea. The upper 45 $\mathrm{cm}$ of soil profile is considered to be the root zone which gives the most of moisture requirements of the cowpea plants. Cowpea was harvested after 90 days as a first stage, after 105 days as a second stage and after 120 days as a final stage from planting. The mean monthly maximum and minimum temperature was $36.10{ }^{\circ} \mathrm{C}$ and $12.1{ }^{\circ} \mathrm{C}$ respectively during the planting season. The soil type of the experimental site was clayey with field capacity, permanent wilting point, and bulk density of $40.61 \%$, $21.81 \%$, and $1.2 \mathrm{~g} / \mathrm{cm}^{3}$, respectively as summarized in Table $\mathbf{1}$ and Table 2.

Composite soil samples were analyzed for texture, field capacity, permanent wilting point and bulk density using standard procedures. Soil moisture samples before irrigation were taken at $10 \mathrm{~m}$ interval along the furrows from each plot at three depths, $0-15 \mathrm{~cm}, 15-30 \mathrm{~cm}$ and $30-45 \mathrm{~cm}$, using soil auger $(0-45 \mathrm{~cm}$ before hilling up irrigation events and at three depths for after hilling up irrigation events) and were determined using 
gravimetric system. The source of irrigation water was available from nearby canal serving the irrigation scheme. Water to irrigate farms on the lower side of the canal is supplied using gravity flow through smaller channels. The field experiments were conducted in the periods June-Oct 2016.

\section{Table 1: Some physical properties of the experiment soil}

\begin{tabular}{|c|c|c|c|c|c|c|c|c|}
\hline \multirow{2}{*}{$\begin{array}{c}\text { Sampling } \\
\text { sector } \\
\text { depth, cm }\end{array}$} & \multicolumn{3}{|c|}{$\begin{array}{c}\text { Particle size } \\
\text { distribution, \% }\end{array}$} & $\begin{array}{c}\text { Texture } \\
\text { class }\end{array}$ & $\begin{array}{c}\text { Bulk } \\
\text { density, } \\
\mathrm{kg} / \mathrm{m}^{3}\end{array}$ & F. C, \% & W. P, \% & $\begin{array}{c}\text { Available } \\
\text { Water, \% }\end{array}$ \\
\hline $0-15$ & 19.50 & 23.45 & 57.05 & clay & 1140 & 43.00 & 22.00 & 21.00 \\
\hline $15-30$ & 18.22 & 22.74 & 49.04 & clay & 1240 & 40.00 & 21.00 & 19.00 \\
\hline $30-45$ & 17.37 & 22.31 & 60.32 & clay & 1320 & 39.00 & 21.00 & 18.00 \\
\hline Mean & 18.36 & 19.16 & 55.47 & clay & 1233 & 40.66 & 21.33 & 19.33 \\
\hline
\end{tabular}

F.C $=$ Field capacity. W.P $=$ Wilting point.

Table 2: Some chemical properties of the experiment soil

\begin{tabular}{|c|c|c|c|c|c|c|c|c|c|c|c|c|c|}
\hline \multirow{2}{*}{$\begin{array}{l}\text { Sector } \\
\text { depth } \\
(\mathrm{cm})\end{array}$} & \multirow{2}{*}{$\begin{array}{l}\text { Ec, } \\
\mathrm{S} / \mathrm{m}\end{array}$} & \multirow{2}{*}{ ESP } & \multirow{2}{*}{$\begin{array}{l}\text { PH } \\
(1: 1)\end{array}$} & \multicolumn{4}{|c|}{$\begin{array}{l}\text { Soluble cations, meq/ } 1 \\
\text { (soil paste extract) }\end{array}$} & \multicolumn{6}{|c|}{ Soluble anions, meg/l (soil paste) } \\
\hline & & & & $\mathrm{Ca}^{++}$ & $\mathrm{Mg}^{++}$ & $\mathrm{Na}^{+}$ & $\mathrm{K}^{+}$ & $\mathrm{Co}^{-} 3$ & $\mathrm{Hco}_{3}$ & $\mathrm{Cl}^{-}$ & So4-- & $\begin{array}{c}\mathrm{O} . \mathrm{M} \\
\%\end{array}$ & $\begin{array}{c}\mathrm{CaCo}_{3} \\
\%\end{array}$ \\
\hline 0 & 3.85 & 5.42 & 78 & 8 & & & & 0 & & & 3 & 0.97 & 1.58 \\
\hline $15-30$ & 3.40 & 6.01 & 8.76 & 6.32 & 10.66 & 15.54 & 0.30 & 0.0 & 10.24 & 10.95 & 11.73 & 0.87 & 1.58 \\
\hline $30-45$ & 3.78 & 8.58 & 8.84 & 5.99 & 10.36 & 20.68 & 0.33 & 0.0 & 12. & 16. & 7.80 & 0.93 & 1.60 \\
\hline Mean & 3.67 & 6.67 & 8.97 & 6.80 & 11.38 & 16.77 & 0.34 & 0.0 & 10.29 & 14.36 & 10.32 & 0.92 & 1.58 \\
\hline
\end{tabular}

\subsection{Experimental Design and treatment setup}

This study conducted on the growth and productivity of Cowpea under Conventional Furrow Irrigation (CFI), Alternate Furrow Irrigation (AFI) and Drip Irrigation (SDI) of water saving technology. The Experimental treatments were irrigation systems and furrow lengths. The irrigation systems were CFI, AFI and SDI while the furrow lengths were $20 \mathrm{~m}, 30 \mathrm{~m}$ and $40 \mathrm{~m}$. The CFI and AFI systems consisted of (pump unit (water electric pumps with $5 \mathrm{hp}$ with maximum discharge $500 \mathrm{l} / \mathrm{min}$ and was connected to the main line by flexible quick hoses)-Control unit (valves on/off-Screen filter 250 mesh-Pressure gauges $2 \mathrm{~m}$ head accuracyFertilization unit)-P.V.C pipes as main lines $(63 \mathrm{~mm}$, inner diameter and $55 \mathrm{~m}$ length)-P.V.C pipes as sub-main lines $(63 \mathrm{~mm}$, inner diameter and $12 \mathrm{~m}$ length)-T shape P.V.C pipes $(25.4 \mathrm{~mm}$, inner diameter and $4 \mathrm{~m}$ length)-T shape control valve FC700 used with 1/2" polyethylene tubing was located in the beginning of each furrow line to control the irrigation 
line).The SDI system consisted of (Electrical valve on/off with flow rate 0.7 to $150 \mathrm{l} / \mathrm{min}$ with a pressure 1 bar to control pressure head and flowP.V.C pipes as main lines (63 mm, inner diameter and $55 \mathrm{~m}$ length)P.V.C pipes as sub-main lines (63 $\mathrm{mm}$, inner diameter and $12 \mathrm{~m}$ length)$\mathrm{T}$ shape P.V.C pipes (25.4 mm, inner diameter and $4 \mathrm{~m}$ length)-Lateral lines (16 mm, inner diameter and $20 \mathrm{~m}, 30 \mathrm{~m}, 40 \mathrm{~m}$ length), wire and bars were used to support laterals to avoid the occurrence of any deflection. Each lateral line was joining to the sub main line by a PLDBV-16 16mm bar screw ball screw - on line emitters $4 \mathrm{l} / \mathrm{h}$ (BLACK)). The experiment was divided into three main fields (plots) separated with buffer zones of $1.4 \mathrm{~m}$. The first plot was (4 m wide x $20 \mathrm{~m}$ long), the second was (4 m wide x $30 \mathrm{~m}$ long) and the third was (4 m wide $\mathrm{x} 40 \mathrm{~m}$ long). The experimental plots were shown in Figure 1 and Table 3 show field layout for the experiment. The experimental field was arranged in a split plot design with three replications where irrigation systems used as a main plot factor and furrow length as sub plot factor. The main plot factor initially assigned randomly in to three sub-blocks. The three furrow length levels randomly assigned within each sub-blocks. The block and plot spacing was $2.0 \mathrm{~m}$ and $1.4 \mathrm{~m}$ respectively. The furrow spacing was equal to row spacing of the cowpea crop. The experimental field had a total number of 36 furrows. Volumetric system was applied to measure flow rate for furrow irrigation. The time required to fill a known volume container of ( 5 liters) was measured. The flow rate is determined by dividing the volume of the container by the time required to fill it by using stop watch.

\section{Table 3: Experimental treatments}

\begin{tabular}{|c|c|c|c|c|}
\hline \multirow{2}{*}{ Irrigation systems } & \multirow{2}{*}{ Irrigation Technique } & \multicolumn{3}{|c|}{ Irrigation length, $(\mathrm{P})$} \\
\cline { 3 - 5 } & & $20 \mathrm{~m}$ & $30 \mathrm{~m}$ & $40 \mathrm{~m}$ \\
\hline \multirow{2}{*}{ Furrow } & Alternative (AFI) $\mathrm{A}$ & $\mathrm{A}_{1} \mathrm{P}_{20}$ & $\mathrm{~A}_{2} \mathrm{P}_{30}$ & $\mathrm{~A}_{3} \mathrm{P}_{40}$ \\
\cline { 2 - 5 } & Conventional (CFI) C & $\mathrm{C}_{1} \mathrm{P}_{20}$ & $\mathrm{C}_{2} \mathrm{P}_{30}$ & $\mathrm{C}_{3} \mathrm{P}_{40}$ \\
\hline Surface drip & Conventional (SDI) $\mathrm{B}$ & $\mathrm{B}_{1} \mathrm{P}_{20}$ & $\mathrm{~B}_{2} \mathrm{P}_{30}$ & $\mathrm{~B}_{3} \mathrm{P}_{40}$ \\
\hline
\end{tabular}

\subsection{Climatic Data Collection}

Climatic data were collected from Rice Research \& Training Center, Sakha, Kaferelsheik, for the year 2016. Evapotranspiration was calculated using Cropwat version 5.7 computer program depending on the average of climatic data of Table 4. 
Table 4: Daily maximum and minimum temperature, wind speed and average daily reference evapotranspiration (ETo) $\mathrm{mm} /$ day for the experimental site

\begin{tabular}{|c|c|c|c|c|c|c|c|}
\hline \multicolumn{8}{|c|}{ Reference evapotranspiration ETo according to Penman - Monteith } \\
\hline \multicolumn{4}{|c|}{ Country : EGYPT } & \multicolumn{4}{|c|}{ Meteo Station : Sakha } \\
\hline \multicolumn{4}{|c|}{ Altitude: 20 meter } & \multicolumn{4}{|c|}{ Coordinates: 31.11 N.L 30.95 E.L } \\
\hline \multirow[t]{2}{*}{ Month } & \multicolumn{2}{|c|}{$\mathrm{T}$ mean, ${ }^{\circ} \mathrm{C}$} & \multirow{2}{*}{$\begin{array}{c}\mathrm{RH} \\
\%\end{array}$} & \multirow{2}{*}{$\begin{array}{c}\mathrm{U} 2 \text {, } \\
\mathrm{Km} / \text { day }\end{array}$} & \multirow{2}{*}{$\begin{array}{c}\mathrm{SH}, \\
\mathrm{h}\end{array}$} & \multirow{2}{*}{$\begin{array}{c}\mathrm{SR}, \\
\mathrm{MJ} / \mathrm{m}^{3} / \text { day }\end{array}$} & \multirow{2}{*}{$\begin{array}{c}\text { ETo, } \\
\mathrm{mm} / \mathrm{day}\end{array}$} \\
\hline & $\mathrm{T}_{\max }$ & $\mathrm{T}_{\min }$ & & & & & \\
\hline April & 29.3 & 12.1 & 63.53 & 89.70 & 12.50 & 30.8 & 4.29 \\
\hline May & 29.6 & 16.7 & 56.05 & 99.30 & 13.00 & 31.5 & 5.62 \\
\hline June & 33.5 & 18.3 & 61.35 & 107.5 & 13.90 & 31.9 & 6.49 \\
\hline July & 33.0 & 19.7 & 65.10 & 102.0 & 13.75 & 32.7 & 6.24 \\
\hline Aug & 36.1 & 20.2 & 67.20 & 105 & 14.85 & 35.4 & 5.50 \\
\hline Sep & 31.6 & 20.2 & 60.47 & 98 & 13.56 & 33.7 & 4.60 \\
\hline Oct & 30.1 & 19.3 & 58.62 & 109 & 13.28 & 31.9 & 3.60 \\
\hline
\end{tabular}

$\mathrm{RH}$ - Relative humidity \%, U2 - Wind velocity Km/day, SH - Sunshine hr, SR - Solar Radiation MJ/m³/day

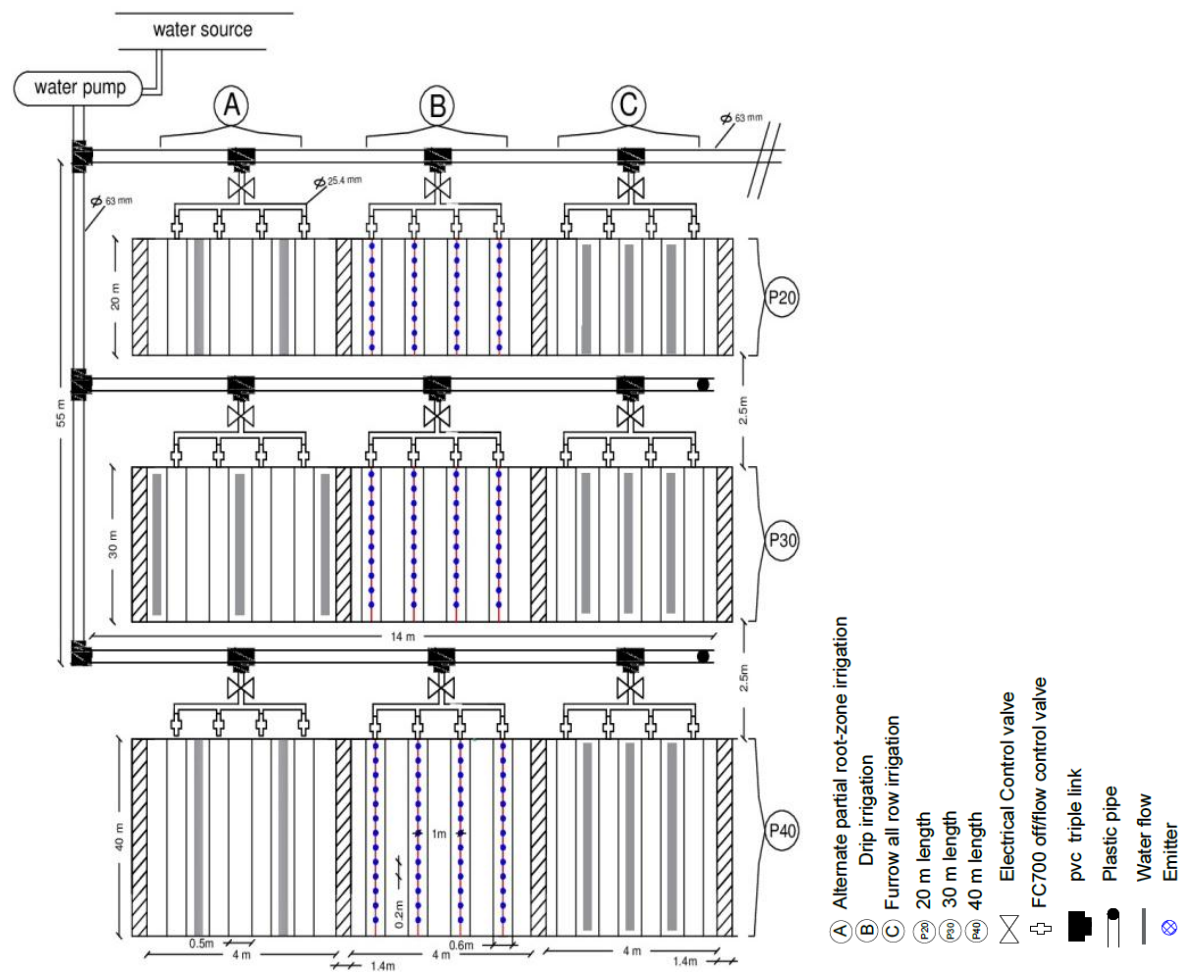

Figure 1: Experimental layout and Design 


\subsection{Gross irrigation requirements}

It was calculated by using the following equation according to $\boldsymbol{F A O}$ (1980).

Where:

$$
I R_{g}=\frac{I R_{n}}{E_{a}}
$$

IRg: gross irrigation requirements, $\mathrm{mm}$ /day; Ea: irrigation system efficiency (assumed $80 \%$ by $\mathbf{H a b i b ~ 1 9 9 2 )}$ and $\mathrm{IR}_{\mathrm{n}}$ : net irrigation requirements ( $\mathrm{mm} /$ day). It was calculated by using the following equation.

$$
\mathrm{IR}_{\mathrm{n}}=\mathrm{ET}_{\text {crop }}+\mathrm{Lr}
$$

Where:

Lr: leaching requirements $\mathrm{mm} / \mathrm{day}$ and $\mathrm{ET}_{\text {crop: }}$ crop water requirements (mm/day).

\section{Inflow time $(T)$}

In order to irrigate each furrow, the time of application was determined by using formula of Hart et al, (1980):

Where

$$
T=\frac{F_{g} \times W \times L}{60 \times Q_{0}} \times 100 .
$$

T: Inflow time of cutoff, min; L: Furrow length, m; W = Furrow spacing, m; Qo: Flow rate, 1/s and Fg: Gross depth of application, $\mathrm{mm}$

\section{Discharge}

The head required to divert each flow rate was determined using the following formula Michael et al (1978):

$$
\mathrm{Q}=\mathrm{Cd} \times \mathrm{A} \times \sqrt{(2 \mathrm{gH})} \times 10^{-3}
$$

Where

Q: Flow rates, 1/s; A: Cross sectional area of pipe, $\mathrm{cm}^{2}$; g: Gravitational acceleration, $981 \mathrm{~cm} / \mathrm{s}^{2} ; \mathrm{H}$ : Effective head, $\mathrm{cm}$ and Cd: discharge coefficient 0.584 . 


\subsection{Soil Moisture content (SMC)}

It was calculated on dry base as follows according to Peters, 1965 and Michael, 1978.

$$
S M C=\frac{\left(W-w_{d}\right)}{W_{d}} \times 100 .
$$

Where

SMC: Soil moisture content, \%; W: Weight of the wet soil sample, $\mathrm{g}$ and $\mathrm{Wd}$ : weight of the dried soil sample, $\mathrm{g}$.

\subsection{Irrigation Performance Indicators}

\section{Available water (AW)}

The readily available water was determined by the following equation according to Michael, 1978.

$$
A W=\frac{(F C-P W P) \times \rho_{s} \times E_{d}}{100} .
$$

Where

AW: Available water 'cm; Fc: Soil moisture content at the field capacity \%; PWP: Soil moisture content at the wilting point \%; Ps: Soil specific density and Ed: Depth of the roots effective $(\mathrm{cm})$.

\section{Depth of irrigation water required}

The Depth irrigation water requirement was determined by the following equation.

$$
\mathrm{Dw}=\mathrm{F}(\mathrm{FC}-\mathrm{WP}) \times \mathrm{Ps} \times \mathrm{Ds} \times \mathrm{P} .
$$

Where:

Dw: Depth of irrigation water to be add it $(\mathrm{cm})$; F: Allowable percentage of depletion from available water (30-70\%); FC: Field capacity, \%; WP: wilting point, \%; Ds: Depth of the soil effective $(\mathrm{cm})$ and P: Wetted area ratio from the total field area $(33 \%)$.

\section{Water Application efficiency (WAE)}

It was defined as the percentage of the stored water in the root zone to the total amount of water applied to the soil. It was determined according to Michael, 1978 and James, 1988 by using the following equation: 


$$
\mathrm{WAE}=\frac{W_{s}}{W_{f}} \times 100
$$

Where:

WAE: Water application efficiency, \%; Ws: Amount of water stored in the root zone, $\mathrm{m}^{3}$ and Wf: Amount of water applied to the field, $\mathrm{m}^{3}$.

\section{Water distribution efficiency (WDE)}

Water distribution efficiency describes how evenly an irrigation system distributes water over the field. It was calculated according to James, 1988 as follows:

$$
\mathrm{WDE}=\left[1-\frac{y}{d}\right] \times 100
$$

Where:

WDE: Water distribution efficiency, \%; y: Average numerical deviation from $\mathrm{d}, \mathrm{cm}$. and $\mathrm{d}$ : Average of soil water depth stored along the furrow during the irrigation, $\mathrm{cm}$.

\section{Leaf area index (L.A.I)}

It was measured by the leaf area meter and the following equation was used to calculate the leaf area index according to El-Zeiny et al. (1989):

$$
\text { L.A.I }=\frac{\text { Leaf area per plant, } \mathrm{cm} 2}{\text { Spacing area per plant, } \mathrm{cm} 2} .
$$

\subsection{Yield and Water Use Efficiency (WUE)}

Water use efficiency has been used to describe the relationship between the cowpea production and the total amount of water used of CFI, AFI and DI. It was determined according to Tennakoon et al., 2003 by using the following equation:

$$
W U E=\frac{Y}{W_{a}}
$$

Where:

WUE: Water use efficiency, $\mathrm{kg} / \mathrm{m}^{3}$; Y: Total yield, $\mathrm{kg} / \mathrm{fed}$ and Wa: Total applied water, $\mathrm{m}^{3} / \mathrm{fed}$. 


\subsection{Statistical analyses:}

The obtained data were subjected to analysis of variance according to the procedures out lined by Snedecor and Cochran (1980). The mean value of treatments was compared according to Duncan's multiple range test, Duncan (DMRT) (1955). The data was analyzed using CoStat software for windows (version 6.3).

\section{RESULTS AND DISCUSSION}

\section{Irrigation Depth (ID)}

The mean Water Irrigation Depth (ID) was 16.17, 12.58 and $10.68 \mathrm{~cm}$ for CFI, AFI and DI irrigation system, respectively. The effect of irrigation system on the ID was significant $(\mathrm{p}<0.01)$. The mean ID was reduced when the furrow length increased from $20 \mathrm{~m}$ to $40 \mathrm{~m}$. Mean ID with respect to furrow length were $14.09,13.24$, and $12.11 \mathrm{~cm}$ for length of 20,30 and $40 \mathrm{~m}$, respectively. The highest ID was $17.65 \mathrm{~cm}$ through the use of furrow irrigation system at the treatment $\mathrm{C}_{1} \mathrm{P}_{20}$ furrows length, while the lowest value was $10.12 \mathrm{~cm}$ for the treatment $\mathrm{B}_{3} \mathrm{P}_{40}$ furrows length with drip irrigation system. Mean values due to the effect of length P20 and P40 on ID were highly significant $(\mathrm{p}<0.01)$ as summarized in Table 5. Interaction effect between irrigation system and furrow length on ID was significant $(p<0.05)$. The highest value was obtained for treatment interaction of smallest furrow length P20 for CFI with mean value of $17.65 \mathrm{~cm}$. The least was recorded for treatment interactions of longer furrow length P40 and SDI with mean value of $10.12 \mathrm{~cm}$. The results of the study indicated that, SDI and AFI systems recorded less water irrigation depth than CFI system by about 51.40 and $28.53 \%$, respectively. And also the water irrigation depth decreased by increasing the furrow lengths line from $20 \mathrm{~m}$ to $40 \mathrm{~m}$ respectively for all systems. It is an evident that by using long furrow length combined with SDI or AFI system, the ID will decrease for all treatments.

\section{Water Application Efficiency (WAE)}

Water application efficiency, WAE, obtained was in the order of $52.46 \%$ to $75.25 \%$ and it was significantly affected $(p<0.01)$ by irrigation system and furrow length. The average application efficiency was increased from 63.48 to $66.77 \%$ when the furrow length increased from $20 \mathrm{~m}$ to 40 $\mathrm{m}$ and also the average application efficiency was increased from 54.60 
to 66.32 and $74.54 \%$ for CFI, AFI and SDI irrigation system, respectively. The maximum application efficiency attained by Eldeiry $\boldsymbol{e t}$ al (2005) was $75.25 \%$ through the use of SDI system at the treatment $\mathrm{B}_{3} \mathrm{P}_{40}$, while the lowest value was $52.46 \%$ for the treatment $\mathrm{C}_{1} \mathrm{P}_{20}$ with CFI system. WAE increased by about of 40.64 and $22.39 \%$ in case of SDI and AFI systems at the treatments P20 furrow length compared with furrow irrigation, while they were 32.62 and $20.40 \%$ at the treatments P40 furrow length, respectively. Mean values due to the effect of length P20 and P40 were highly significant $(\mathrm{P}<0.01)$ only as summarized in Table 5 and Fig 2. Interaction effect between irrigation system and furrow length on WAE was also highly significant $(\mathrm{p}<0.01)$. The highest value was obtained for treatment interaction of longer furrow length P40 for DI with mean value of $75.25 \%$. The least was recorded for treatment interactions of smallest furrow length P20 and CFI with mean value of $52.46 \%$. The results of the study indicated that, the SDI and AFI systems recorded higher application efficiency than CFI by about 36.52 and $21.46 \%$, respectively. And also the water application efficiency increased by increasing the furrow lengths line from $20 \mathrm{~m}$ to $40 \mathrm{~m}$ respectively from all systems. It is an evident that by using long furrow length combined with SDI or AFI system, WAE can be enhanced. This is in agreement with the result of Eldeiry et al 2005 and Khalifa, (2009).

\section{Water Distribution Efficiency (WDE)}

WDE was highly significant $(\mathrm{p}<0.01)$ influenced by irrigation system and furrow length. The mean WDE was reduced when the furrow length increased from $20 \mathrm{~m}$ to $40 \mathrm{~m}$. Mean WDE with respect to furrow length were $60.26,58.29$, and $53.33 \%$, for 20,30 and $40 \mathrm{~m}$ furrow length, respectively. Usually the variation of furrow dimensions and contact times in the use of short furrows are very low as compared to longer furrows. As a result, more uniformity occurred in short furrows and the relationship between WDE and furrow length was reverse. The WDE was significantly $(\mathrm{p}<0.01)$ influenced by the irrigation system. Unlike to furrow length, the rise in mean irrigation system from 39.97 to 61.23 and $70.67 \%$ for CFI, AFI and SDI irrigation system, respectively improved the WDE. The increasing trend of WDE with flow rate which achieved by using different irrigation systems was in agreement with [Sewnet 
EshetuAnmut, 2007] and [Melaku, M., 2005]. Mean values due to the effect of length P20 and P30 on WDE were not significant ( $>0.01)$, whereas that of length $\mathrm{P} 40$ and $\mathrm{P} 20$ were highly significant $(\mathrm{P}<0.01)$ as summarized in Table 5 and Figure 2. Interaction effect between irrigation system and furrow length on WDE was also highly significant $(\mathrm{p}<0.01) . \mathrm{B}_{1} \mathrm{P}_{20}$ has resulted highest mean WDE $(73.37 \%)$ due to the fast advancing rate and low contact time variation of short furrow length. Whereas, furrow irrigation system combined with the longest furrow length $\left(\mathrm{C}_{3} \mathrm{P}_{40}\right)$ could result the lowest WDE, 36.45\%.

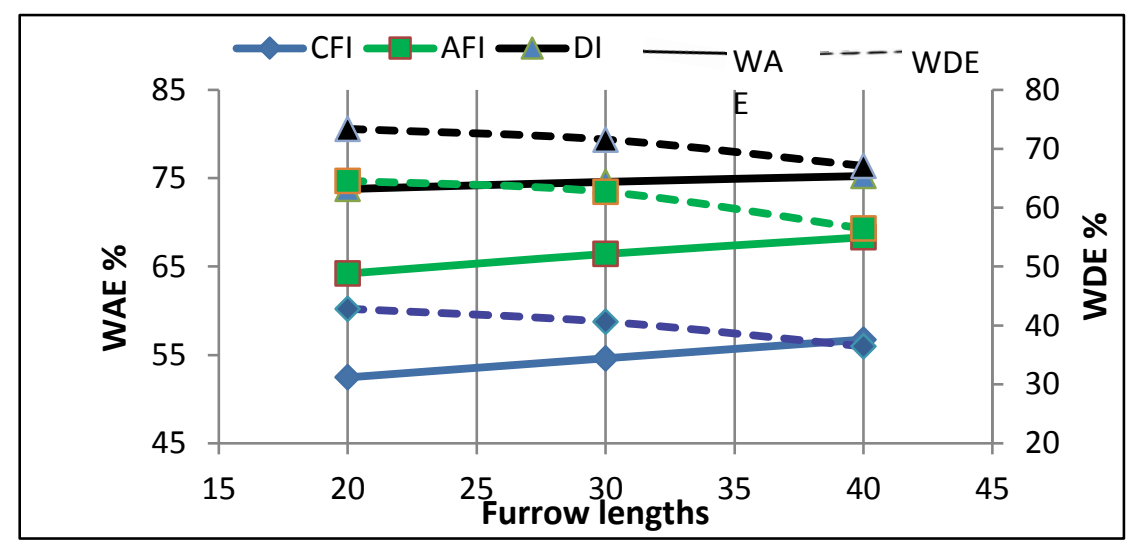

Figure 2: Relationships between Furrow lengths, WAE and WDE

The results demonstrated that in case of increasing furrow length line, the water distribution efficiency will decrease for all treatments. Therefore, the P20 treatment gave the best values of water distribution efficiency compared with the other treatments. And also the WDE developed by using SDI and AFI systems under all treatments compared with CFI system by about 76.80 and $53.18 \%$, respectively. This attributes to ability to deliver the decided amount of water to the plants at the proper time. Values of water distribution efficiency were agreement with Khalifa, (2009).

\section{Applied Water amounts under investigated technique (AW)}

The maximum value of the total applied water (AW) was $1891.01 \mathrm{~m}^{3} / \mathrm{fed}$ with CFI system, while 1086.01 and $1057.56 \mathrm{~m}^{3} / \mathrm{fed}$ was applied to the AFI and SDI systems. This shows that the subplots under AFI used roughly half the amount of water compared to the subplots under CFI. It 
is concluded that, the SDI give the lowest values of amount of the water applied during the growth season comparing with all treatments. The WA was significantly affected $(\mathrm{p}<0.01)$ by irrigation systems and irrigation technique. The average of water applied was increased from 33.11 to 38.34 and $43.88 \mathrm{~m}^{3}$ when the furrow length increased from $20 \mathrm{~m}$ to $30 \mathrm{~m}$ and $40 \mathrm{~m}$ and also the average AW was decreased from 54.06 to 31.04 and $30.23 \mathrm{~m}^{3}$ for CFI, AFI and SDI irrigation system, respectively as summarized in Table 5 and Figure 3.

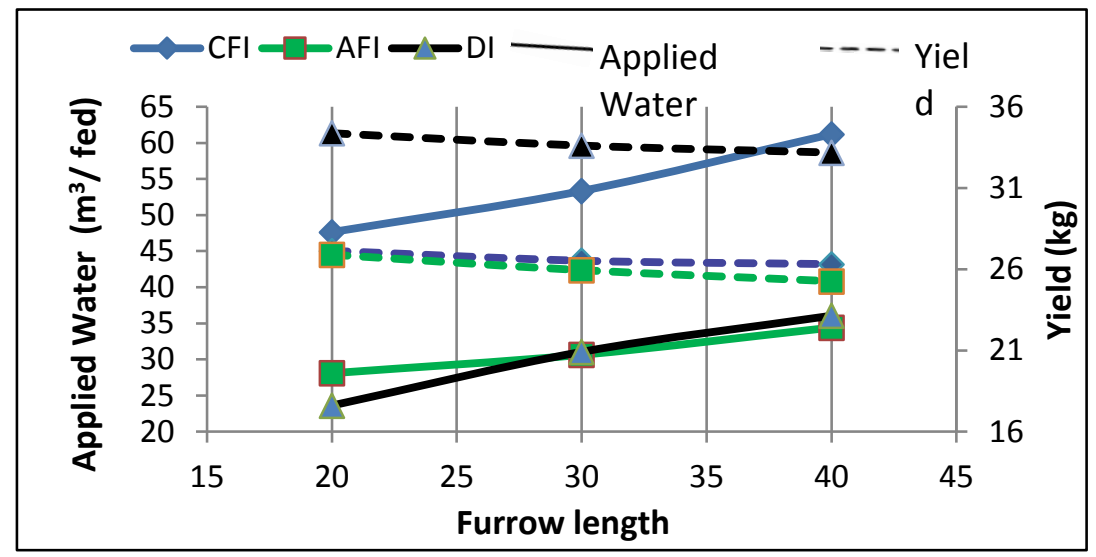

Figure 3: Relationships between Furrow lengths, Applied Water and Yield

Interaction effect between irrigation systems and furrow lengths on AW was not significant. The maximum AW was $61.20 \mathrm{~m}^{3}$ through the use of CFI system at the treatment $\mathrm{C}_{3} \mathrm{P}_{40}$, while the lowest value was $23.61 \mathrm{~m}^{3}$ for the treatment $\mathrm{B}_{1} \mathrm{P}_{20}$ with SDI system. The average WA was increased by about of 15.79 and $32.52 \%$ by using length P30 and P40 compared length P20 but it was decreased by about of 42.58 and $44.08 \%$ by using AFI and SDI systems, respectively. Mean values due to the effect of AFI and SDI system on WA were not significant $(\mathrm{p}>0.01)$, whereas that of CFI and AFI system were highly significant $(\mathrm{P}<0.01)$. Our results align with the 40 to $46 \%$ water savings obtained using AFI and DI compared with CFI which were agree with Slatni et al. (2011).

Generally, when compared to CFI, the saved water obtained with AFI technique was about $42.58 \%$ and the saved water obtained with DI was about $44.08 \%$. When compared to AFI, the saved water obtained with DI was about $2.6 \%$. Fig 3.3 showed the water saving between treatments 
according to length $40 \mathrm{~m}$. The statistical analysis of the cowpea water saved obtained in our experiment showed that the difference in water saved obtained with AFI and SDI was non-significant $(\mathrm{p}>0.01)$ as summarized in Figure 4.

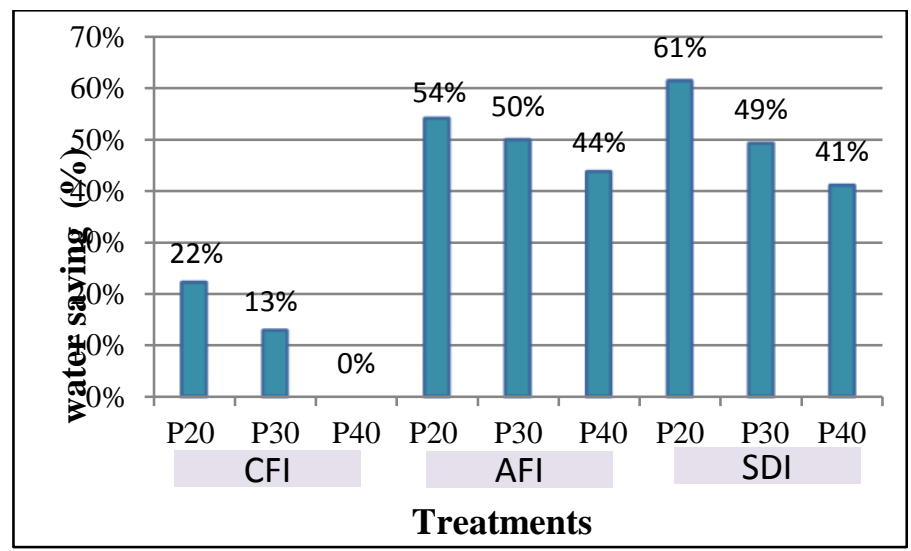

Figure 4: Water saving between treatments according to length $40 \mathrm{~m}$

\section{Leaf area index}

Leaf area index obtained was in the order of 2.99 to 2.37 and it was significantly affected $(\mathrm{p}<0.05)$ by irrigation system only. The average leaf area index was decreased from 3.94 to 2.48 and 1.59 for CFI, AFI and SDI, respectively. Mean values due to the effect of irrigation system on plant leaf area was highly significant $(\mathrm{P}<0.01)$ as summarized in Table 5. Interaction effect between irrigation system and furrow length on Leaf area index was also highly significant $(p<0.05)$. The highest value was obtained for treatment interaction of smallest furrow length P20 and CFI with mean value of 2.99 and the least Leaf area index was recorded for treatment interactions of longer furrow length P40 and SDI with mean value of 2.37. The results of the study indicated that, the CFI system recorded higher leaf area index than SDI and AFI systems.

\section{Cowpea Grain Yield}

The effect of irrigation system on cowpea grain yield was significant $(\mathrm{p}<0.01)$. The average cowpea yield gained was $1179.52 \mathrm{~kg} / \mathrm{fed}$. The maximum and minimum yield was obtained from the treatment $\mathrm{B}_{3} \mathrm{P}_{20}$ $(34.37 \mathrm{~kg})$ and $\mathrm{A}_{3} \mathrm{P}_{40}(25.26 \mathrm{~kg})$ respectively. When the maximum yield obtained, greater performance in application efficiency and water use 
efficiency was recorded. The mean cowpea yield was 932.33, 910.52 and $1179.52 \mathrm{~kg} /$ fed for CFI, AFI and SDI, respectively. The average cowpea yield was increased from 26.65 to $33.72 \mathrm{~kg}$ for CFI and SDI by about of $26.52 \%$. The effect of furrow length and its interaction with irrigation system could not show significant effect $(\mathrm{P}<0.05)$ on the cowpea yield. It was decreased from 29.46 to $28.25 \mathrm{~kg}$ for length P20 and P40 by about of $4 \%$, respectively. Mean values due to the effect of irrigation system on cowpea yield between CFI and AFI systems were not significant ( $p>0.01$ ), whereas that between SDI and CFI or AFI were highly significant $(\mathrm{P}<0.01)$ as summarized in Table 5, Figures 3 and 5.

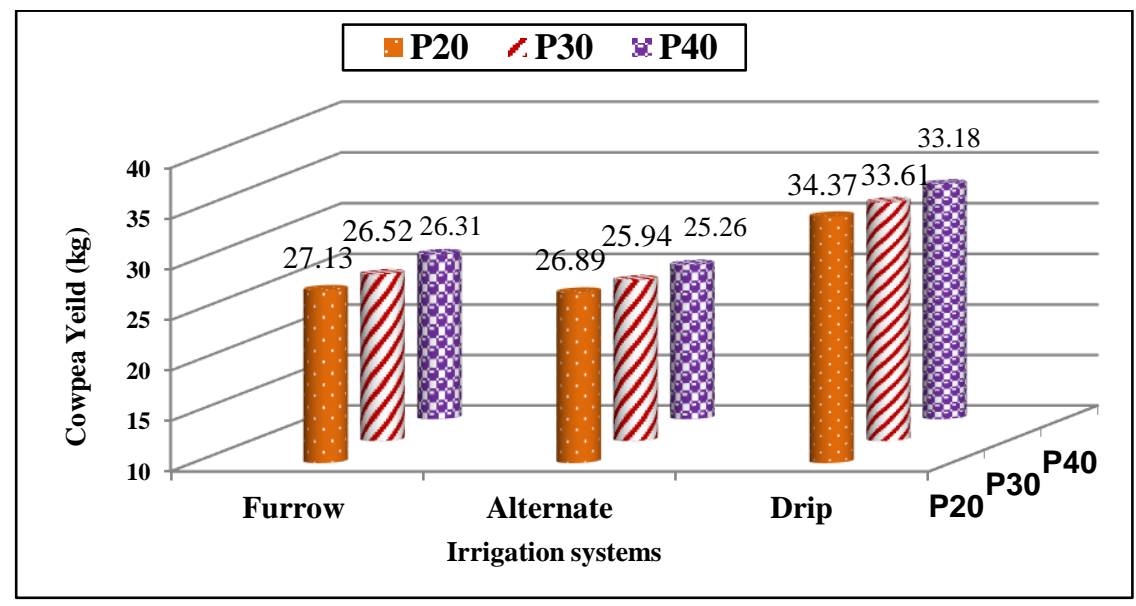

\section{Figure 5: Relationships between irrigation systems and furrow length on cowpea yield}

However, the rise of water applied for CFI could not increases the yield because most of the water has turned in to surface runoff. The effect of furrow length and its interaction with irrigation system between CFI and AFI could not show significant effect $(\mathrm{P}<0.01)$ on the cowpea yield. Better cowpea yield was obtained at SDI system. This happens due to the fact that better irrigation uniformity was attained in higher water use and application efficiency. The results of the study indicated that, SDI recorded higher cowpea yield than AFI or CFI system by about $26 \%$ and also the result indicated that no significant difference of cowpea yield between CFI and AFI systems. The cowpea yield decreased by increasing the furrow lengths line from 20 to 30 and $40 \mathrm{~m}$ but not significant effect. The results agree with the result of Rafiee et al. (2010). 


\section{Water Use Efficiency (WUE)}

The mean water use efficiency (WUE) was $16.90 \mathrm{~kg} / \mathrm{m}^{3}$. The effect of irrigation system on the WUE was significant $(\mathrm{p}<0.01)$. The average WUE was decreased from 11.57 to $8.10 \mathrm{~kg} / \mathrm{m}^{3}$ when the furrow length increased from $20 \mathrm{~m}$ to $40 \mathrm{~m}$. Mean values due to the effect of length P20 and $\mathrm{P} 40$ was highly significant $(\mathrm{P}<0.01)$ only. The average WUE was increased from 5.81 to 9.87 and $13.41 \mathrm{~kg} / \mathrm{m}^{3}$ for CFI, AFI and SDI systems. The highest WUE was $16.90 \mathrm{~kg} / \mathrm{m}^{3}$ which attained by $\mathrm{B}_{1} \mathrm{P}_{20}$ due to the presence of more moisture in the root zone as compared to the other treatments for SDI, while the less WUE was $5.81 \mathrm{~kg} / \mathrm{m}^{3}$ was attained by $\mathrm{c}_{3} \mathrm{P}_{40}$ due to the presence of less moisture in the root zone as compared to the other treatments for CFI. Mean values due to the effect of irrigation system on WUE was highly significant $(\mathrm{P}<0.01)$ as summarized in Table 5 and Fig 6. Similarly, the effect of furrow length was not significant on the WUE between P30 and P20 or P40 and also the interaction effect between irrigation system and furrow length on WUE was also highly significant $(\mathrm{p}<0.01)$.

The results of the study indicated that, DI recorded higher WUE than AFI by about $35.54 \%$ and AFI recorded higher WUE than CFI by about $74.73 \%$. And also the WUE decreased by increasing the furrow lengths line from 20 to $40 \mathrm{~m}$ for all systems. It is an evident that by using long furrow length combined with DI or AFI system, the WUE will increase for all treatments. This is in agreement with the result of Ibrahim et al. 2010, Slatni et al. 2011, Acar et al. 2014 and Sahin et al. 2014.

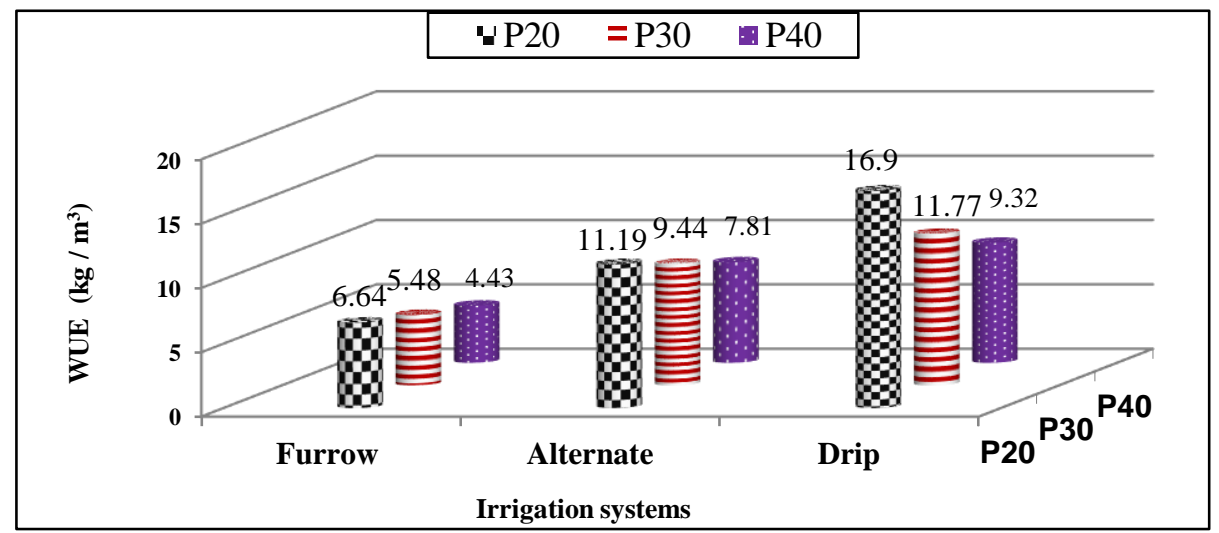

Figure 6: Relationships between irrigation systems and furrow length on cowpea yield 
Table 5: Irrigation depth (cm), Applied water $\left(\mathrm{m}^{3} / \mathrm{fed}\right)$, Water application efficiency \%, Water distribution efficiency \%, Leaf area index, Yield (kg/fed) and Water use efficiency $\left(\mathrm{kg} / \mathrm{m}^{3}\right)$ accumulation of cowpea as affected by the interaction between Irrigation system and length

\begin{tabular}{|c|c|c|c|c|c|c|c|c|c|}
\hline \multirow{2}{*}{$\begin{array}{l}\text { Irrigation } \\
\text { systems }\end{array}$} & \multirow{2}{*}{$\begin{array}{l}\text { Irrigation } \\
\text { Technique }\end{array}$} & \multirow{2}{*}{$\begin{array}{l}\text { Length } \\
\text { (L) }\end{array}$} & \multicolumn{4}{|c|}{ Irrigation Water Indices } & \multicolumn{2}{|c|}{ Yield Indices } & \multirow{2}{*}{ WUE } \\
\hline & & & ID & AW & WAE & WDE & LAI & Yield & \\
\hline \multirow{6}{*}{$\begin{array}{c}\text { Furrow } \\
\text { Irrigation } \\
\text { System }\end{array}$} & \multirow{3}{*}{$\begin{array}{c}\text { Conventional } \\
\text { CFI }\end{array}$} & 20 & $17.65 \mathrm{a}$ & 47.64 & $52.46 \mathrm{~g}$ & $42.84 \mathrm{e}$ & $2.99 \mathrm{a}$ & $27.13 \mathrm{dc}$ & $6.64 \mathrm{e}$ \\
\hline & & 30 & $16.52 \mathrm{~b}$ & 53.34 & $54.62 \mathrm{f}$ & $40.63 \mathrm{e}$ & $2.94 \mathrm{a}$ & $26.52 \mathrm{~d}$ & $5.48 \mathrm{e}$ \\
\hline & & 40 & $14.35 \mathrm{c}$ & 61.20 & $56.74 \mathrm{e}$ & $36.45 \mathrm{f}$ & $2.89 \mathrm{ab}$ & $26.31 \mathrm{~d}$ & $4.43 \mathrm{e}$ \\
\hline & \multirow{3}{*}{$\begin{array}{c}\text { Alternative } \\
\text { AFI }\end{array}$} & 20 & $13.42 \mathrm{c}$ & 28.09 & $64.21 \mathrm{~d}$ & $64.57 \mathrm{c}$ & $2.52 \mathrm{abc}$ & $26.89 \mathrm{~d}$ & $11.19 \mathrm{c}$ \\
\hline & & 30 & $12.46 \mathrm{c}$ & 30.64 & $66.43 \mathrm{c}$ & $62.68 \mathrm{c}$ & $2.49 \mathrm{abc}$ & $25.94 \mathrm{de}$ & $9.44 \mathrm{~d}$ \\
\hline & & 40 & $11.87 \mathrm{~d}$ & 34.41 & $68.32 \mathrm{~b}$ & $56.45 \mathrm{~d}$ & $2.42 \mathrm{abc}$ & $25.26 \mathrm{de}$ & $7.81 \mathrm{~d}$ \\
\hline \multirow{3}{*}{$\begin{array}{l}\text { Surface } \\
\text { Drip }\end{array}$} & \multirow{3}{*}{$\begin{array}{c}\text { Conventional } \\
\text { SDI }\end{array}$} & 20 & $11.20 \mathrm{de}$ & 23.61 & $73.78 \mathrm{a}$ & $73.37 \mathrm{a}$ & $2.42 \mathrm{abc}$ & $34.37 \mathrm{a}$ & $16.90 \mathrm{a}$ \\
\hline & & 30 & 10.74 ef & 31.04 & $74.59 \mathrm{a}$ & $71.56 \mathrm{a}$ & $2.39 \mathrm{bc}$ & $33.61 \mathrm{ba}$ & $11.77 \mathrm{~b}$ \\
\hline & & 40 & $10.12 \mathrm{f}$ & 36.05 & $75.25 \mathrm{a}$ & $67.09 \mathrm{~b}$ & $2.37 \mathrm{c}$ & $33.18 \mathrm{~b}$ & $9.32 \mathrm{~b}$ \\
\hline
\end{tabular}

Means in each column designated by the same letter are not significantly different at $5 \%$ level using Duncan's Multiple Range Test

\section{CONCLUSION}

This study showed that the use of different irrigation systems and techniques have shown different outcomes. Irrigation system has a significant effect of on the yield, crop water use efficiency, irrigation performance indicators and vegetative growth. The DI and AFI systems have improved certainly the yield, WAE, WDE, WS and WUE. The use of CFI was seen with highest WA and ID, lowest adequacy of water and low yield production. In the situation of furrow length rise from $20 \mathrm{~m}$ to $40 \mathrm{~m}$ the yield, WUE, WDE and ID were decreased, while the WAE and WA were increased. Hence, in the utilization of fragmented farm size, the combination of $40 \mathrm{~m}$ furrow length with using DI or AFI systems can be used for better crop yield, and irrigation efficiency because furrow length could not show significant effect $(\mathrm{P}<0.05)$ on the cowpea yield. In addition, the users should give much emphasis in reducing furrow gradient in order to improve the distribution uniformity.

\section{REFERENCES}

Acar B.; R. Topak; D. Yavu and M. A. Kalender (2014). Is Drip irrigation technique sustainable solution in agriculture for semi-arid 
regions? A case study of Middle Anatolian region. Turk In. J. Agric. Econ. Dev. 2(2):1-8

Anmut, S. E. (2007). Evaluation of the Effect of Flow Rate and Furrow Length on Irrigation Efficiencies and Water Use. M.Sc. Thesis. Haramaya University.

Assefa, S.; Y. Kedir and T. Alamirew (2017). Effects of Slopes, Furrow Lengths and Inflow Rates on Irrigation Performances and Yield of Sugarcane Plantation at Metehara, Ethiopia. Irrigat Drainage Sys Eng 6: 179.

Bahrani, A. and J. Pourreza, (2016). Effect of alternate furrow irrigation and potassium fertilizer on seed yield, water use efficiency and fatty acids of rapeseed. Volumen $34, \mathrm{~N}^{\circ} 2$. Páginas 35-41 IDESIA (Chile) Abril, 2016.

Bakker, D. M.; S. R. Raine and M. J. Robertson (1995). A preliminary investigation ofalternate furrow irrigation for sugar cane production. In: Conference Proc.'Clean Water-Clean Environment21st Century, March 1995, Kansas City, Missouri, ASAE.

Chiulele, R. M. (2010) Breeding Cowpea for Improved Drought Tolerance in Mozambique. PhD Thesis, University of Kwazulu Natal.

Du, T. S.; S. Z. Kang; J. S. Sun; X. Y. Zhang and J. H. Zhang (2010). An improved water use efficiency of cereals under temporal and spatial deficit irrigation in north China. Agricultural Water Management 97(1), 66-74.

Duncan, D.B. (1955). Multiple range and multiple F tests. Biometrics, 11:1-42.

Eldeiry, A. A.; L. A. Garcia; A. S. A. El-Zaher and E. M. Kiwan (2005). Furrow Irrigation System Design for Clay Soils in Arid Regions. American Society of Agricultural Engineers. Vol. 21(3): 411-420.

El-Shaieny, A. H. (2017). Drought tolerance of some cowpea genotypes under Upper Egypt conditions. Nat Sci 2017;15(5):22-29]. ISSN 1545-0740 (print); ISSN 2375-7167. 
El-Zeiny, H. A.; A. K. AbdEl-Halim and A. A. El-Noemani (1989). Response of maize to irrigation intervals nuder different levels of Phosphours fertilization. Egypt. J. Appl. S., 4(4): 1- 11.

FAO (1980). Irrigation and drainage, paper 36. Localized irrigation. Rome.

Felipe, H. B. and L. E. Jackson (2011). Alternate Furrow Irrigation Reduces Water Applied without Yield Reduction in California Processing Tomatoes, The Western Sustainable Agriculture Research and Education (Western SARE - GW 10-010)

Fereres, E. and M. A. Soriano (2007). Deficit irrigation for reducing agricultural water use. Special issue on 'Integrated approaches to sustain and improve plant production under drought stress'. J Exp Bot 58:147-159

Golzardi, F.; A. Baghdadi and K. Afshar (2017). Alternate furrow irrigation affects yield and water-use efficiency of maize under deficit irrigation. Crop and Pasture Science 68(8) 726-734.

Habib, I. M. (1992). Irrigation systems of desert lands for open education students (In Arabic text book). Cairo Univ.

Hart, W. E.; H. G. Collins; G. Woodward and A. S. Humpherys (1980). Design and operation of gravity or surface irrigation systems. In M. E. Jensen (ed.), Chap. 13 Design and Operation of Farm Irrigation Systems. American Society of Agricultural Engineers. Michigan. No. 3. pp. 501-580.

Horst, M. G.; S. S. Shamutalov; L. S. Pereira and J. M. Goncalves (2005). Field assessment of the water saving potential with furrow irrigation in Fergana, Aral Sea basin. Agricultural Water Management 77(1-3), 210-231.

Ibrahim, M. A. M. and T. K. Emara (2010). Water saving under alternative furrows surface Irrigation in clay soils of north Nile delta. Fourteenth International Water Technology Conference (IWTC), Cairo, Egypt (21-23 March 2010), 811-821.

James, L. G. (1988) "Principles of farm irrigation system design". John willey \& sons, inc. 
Khalifa, E. M. A. (2009). "Sugar beet production under drip irrigation in heavy clay soil". Ph.D. Thesis, Ag. Mech. Dept., Fac. Ag., kaferelsheik University, Egypt.

Mashori, A. S. (2013). Evaluation of the performance of the alternate furrow irrigation under climatic conditions of Sindh. M. E. Thesis, Sindh Agriculture University, Tandojam, Pakistan

Michael, A. M. (1978). Irrigation Theory and Practice, Vikas Publishing House Ltd. New Delhi. pp.547-568.

Michael, A. M.; S. Mohan and K. R. Swaminathan (1972). Design and Evaluation of Irrigation Systems.Water Technology Center, Indian Agricultural Research Institute. New Delhi. 189p

Montoro A, L.-F. P. (2011). Improving on-farm water management through an irrigation scheduling service. Irrigation Science, 29,311319.

Mulei, M. J. (2015). Growth and yield of selected vegetables under alternate furrow irrigation in the "ASAL" areas of Eastern Kenya. Jomo Kenyatta University of Agriculture and Technology.

Peters, D.B. (1965). " Water availability." In "Systems of soil analysis". Amer. Soc. Agron. Mon., 9:281.

Rafiee, M. and G. Shakarami (2010). Water use efficiency of corn as affected by every other furrow irrigation and planting density. World Appl. Sci. J. 11 (7), 826-829.

Sahin, U.; S. Ors; F. M. Kiziloglu and Y. Kuslu (2014). Evaluation of water use and yield responses of drip-irrigated sugar beet with different irrigation techniques. Chil J Agric Res 74:302-310

Sander, J. Z. and M. Luice (2010). A remote sensing-based irrigation performance assessment - A case study of office DU Niger in Mali. Irrigation Science, 28,371-385.

Sepaskhah, A. R. and M. Ghasemi (2008). Every other furrow irrigation with different intervals for sorghum. Pak J. Biol. Sci. 11 (9), 1234-1239.

Siyala, A.A.; A.S. Mashorib; K. L. Bristowc and M. Th. Genuchten (2016). Alternate furrow irrigation can radically improve water productivity of okra, Agricultural Water Management 173 (2016) $55-60$ 
Slatni, A.; K. Zayani; A. Zairi; S. Yacoubi; R. Salvador and E. Playan (2011). Assessingalternate furrow strategies for potato at the Cherfech irrigation district ofTunisia. J. Biosyst. Eng. 108 (2), 154-163.

Snedecor, G.W. and W. G. Cochran (1980). Statistical systems, 7th Ed. Iowa State Univ. Press, Ames, Iowa, USA.

Stickic R, P. S. (2003). Partial Root Drying-A new Technique for growing plants that saves water and improves quality of fruit. Bulgarian Journal Of Plant Physiology , special issue;164-171.

Stone, J. F., and D. L. Nofziger (1993). Water use and yields of cotton grown underwide-spaced furrow irrigation. Agric. Water Manag. 24 (1), 27-38.

Tennakoon, S. B. and S. P. Milroy (2003). Crop water use and water used efficiency on irrigated cotton farms in Australia. Agricultural Water Management.Vol. 61, pp.179-194.

Yigezu, T.T. and K. Narayanan (2016). Effect of Furrow Length and Flow Rate on Irrigation Performances and Yield of Maize. International Journal of Engineering Research \& Technology (IJERT), ISSN: 2278-0181, Vol. 5 Issue 04, April-2016.
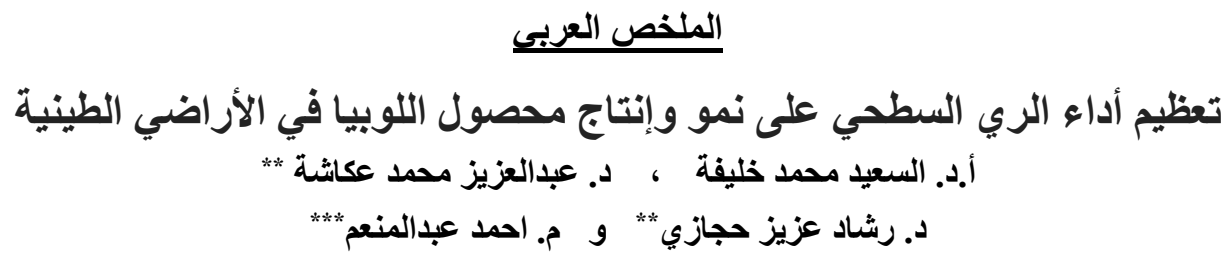

يعتبر محصول اللوبيا من المحاصيل الحيوية والرئيسية بين البقوليات النباتية الموجودة في

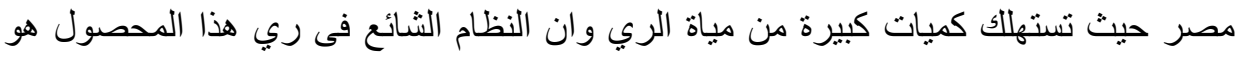

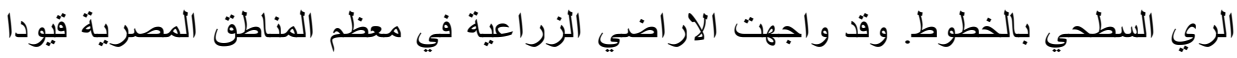

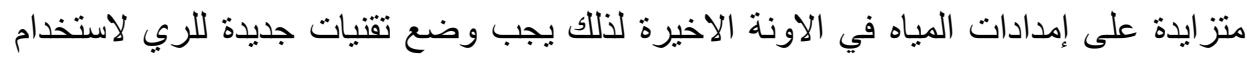

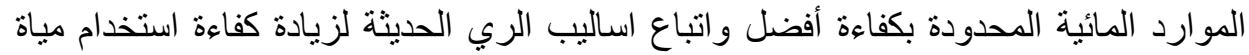

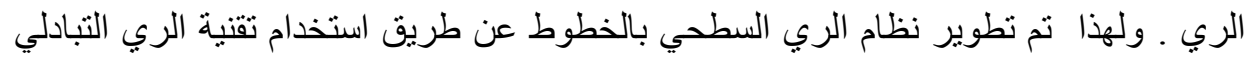

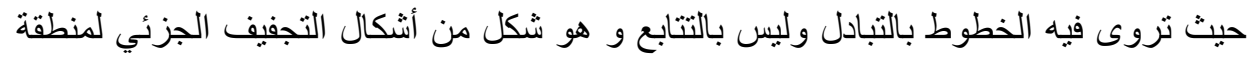

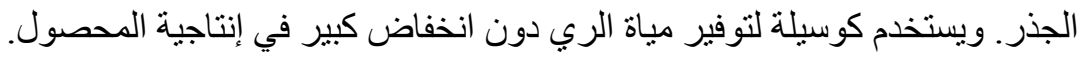

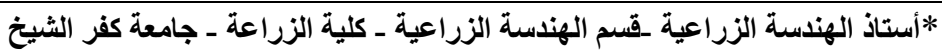

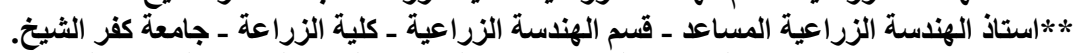

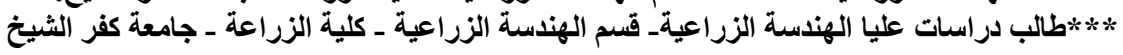


ولقد أجريت التجارب الحقلية في المزرعة التجريبية، كلية الزراعة جامعة كفر الثيخ خلال

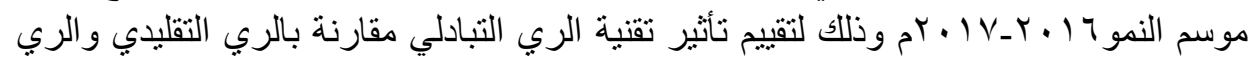

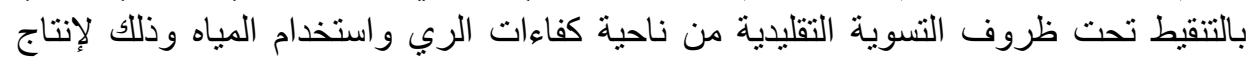

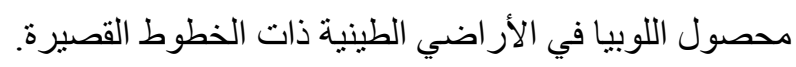

وقد اشتملت الاراسة على المعاملات التالية :

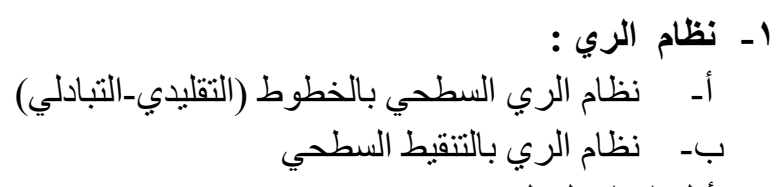

r- أطوال الخطوط :

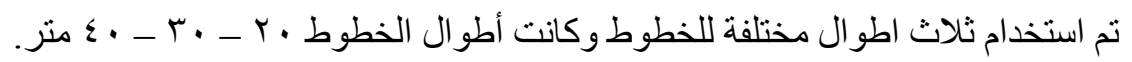

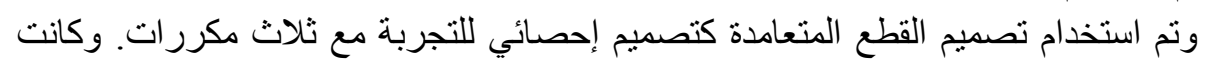

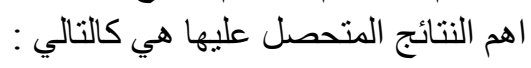

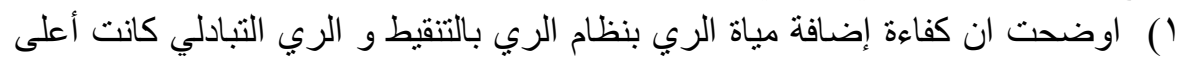

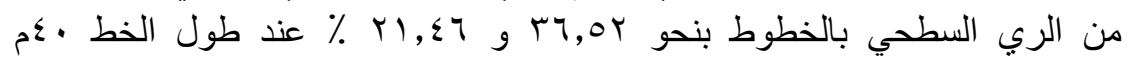

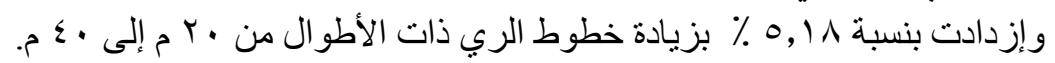

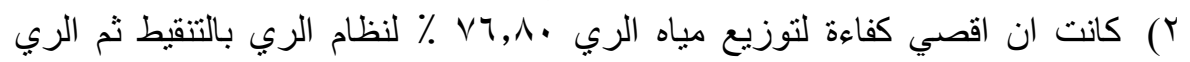

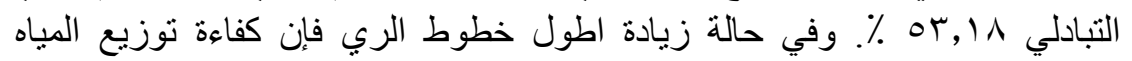

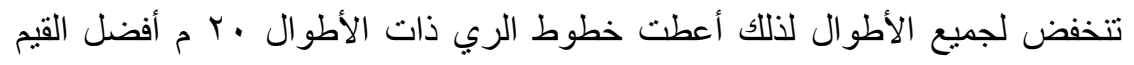

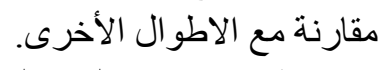

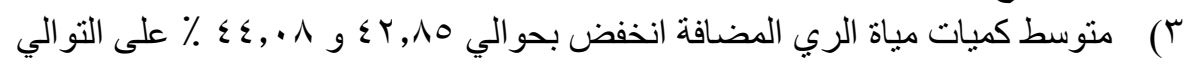

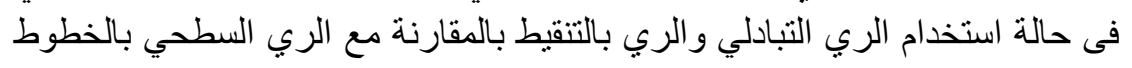

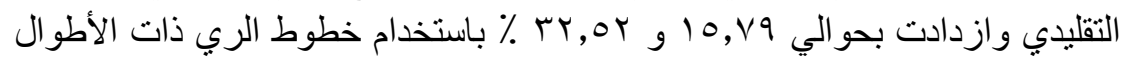

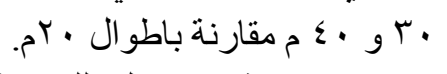

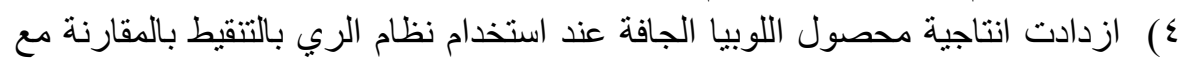

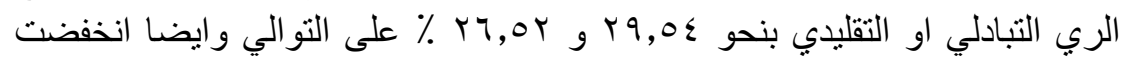

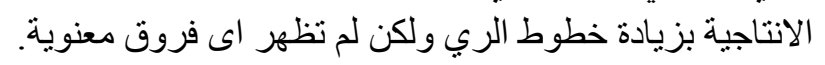

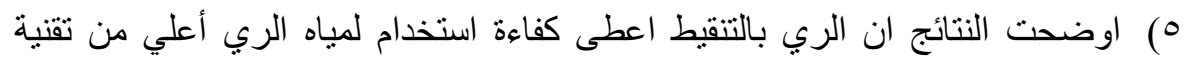

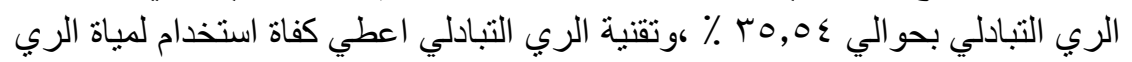

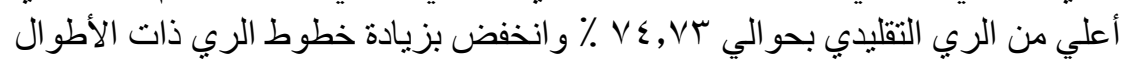

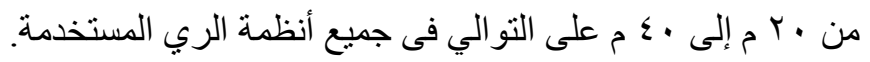

ومن النتائج السابقة نجد ان الري بالتنقيط هو افضل الاختيار ات وفى حالة تعذر تطبيقه يكون

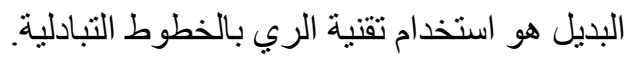

